\title{
Soil organic characterisation in forensic case work
}

The James Hutton Institute, Craigiebuckler, Aberdeen AB15 8QH, Scotland, UK; Treasurer, International Union of Geological Sciences, Initiative on Forensic Geology (IUGS-IFG); *Corresponding author, E-mail: Lorna.Dawson@hutton.ac.uk

(Received: December 1, 2016; Revised accepted: March 17, 2017)

http://dx.doi.org/10.18814/epiiugs/2017/v40i2/017018

Soils are composed of natural inorganic and organic (both natural plant and animal and also man-made) components. The organic soil profile is complex, and there is a range of analytical methods available; however, the organic characteristics strongly complement that of the soil inorganic profile characteristics to provide a complete soil analytical profile, allowing detailed comparison and evaluation of soil recovered from questioned items with soil at a crime scene and to also provide clues in crime reconstruction and in search operations. Organic profiles can provide information about a range of soil forming features such as the vegetation present, land use past and present, altitude, etc., as well as providing information about nearness to industry and roads, tracks and rail networks and infrastructure. Biomarkers which remain in soil as a result of body decomposition can also be analysed and used in search and to help locate human remains.

\section{Introduction}

\section{Soil Characteristics and Analysis}

Soils are composed of both inorganic (e.g., minerals) and organic (e.g., plant derived) constituents (Fig. 1). The approach taken and methods chosen when characterising soil in forensic case work often depend upon the availability of the equipment, their costs, resolution, as well as the size and condition of the questioned samples available. Consideration has to be given to the destructive nature of an analysis technique and the sequence of analysis; it is preferable to carry out non-destructive analyses before the sample is destroyed. In addition, consideration should be given to the potential strength of evidence which depends upon the number of measurements made (Pye, 2007) and the complementarity of such measurements (Dawson and Hiller, 2010).

Soil evidential samples can often be very restricted in size, which may limit the range of options for choice of analytical methods. Furthermore, these samples may contain many more materials than are considered to be normal components of soil. Transfer and persistence of material has also to be considered, and careful assessments must be made so that similar size factions are compared in any analysis (e.g., Bull et al., 2006). The moisture content of the soil at time of transfer is also important, as is the condition of the contact location soil, such as depth of contact with for example a puddle on the road.

Inorganic methods such as chemical and mineralogical approaches have been most generally applied in case work. Persistent biological approaches such as through the use of palynology or wax marker analysis has also been used in some developed countries (e.g., New Zealand, UK, and The Netherlands), either in addition to the characterisation of the inorganic component, or on its own, often when a restricted sample is available. Recently however, analysis of individual aggregates has allowed greater comparator analysis involving soil organic matter (such as in R v. Muir, 2013, HMA v. Sinclair, 2014 and R v. Halliwell).

Detritus picked up from urban pavements and street gutters as well as faecal material can also be analysed using the same combined inorganic and organic approach; chosen analytical approaches are also applicable to these materials. The broad spatial variation in soil, roadway, water, building materials, and air and water borne particles can be contrasted with the variation in urban materials, from dwellings to streets or parks or gardens, along with micro-spatial variation in each (Ruffell et al., 2013).

One nondestructive approach which informs on the organic component as well as the inorganic component is Fourier Transform Infrared Spectroscopy (FTIR) and Diffuse Reflectance Infrared Fourier Transform (DRIFT). FTIR and DRIFT spectroscopy are non-destructive and can be rapidly applied (Robertson et al., 2015). The mid-infrared portion of the electromagnetic spectrum is sensitive to organic materials, clay minerals, and quartz because of the absorption of infrared light at the vibrational frequencies of molecular functional groups constituting these materials (e.g., Nguyen et al., 1991). As such, mid-infrared spectroscopy is a rapid but qualitative tool, which can be used to characterise

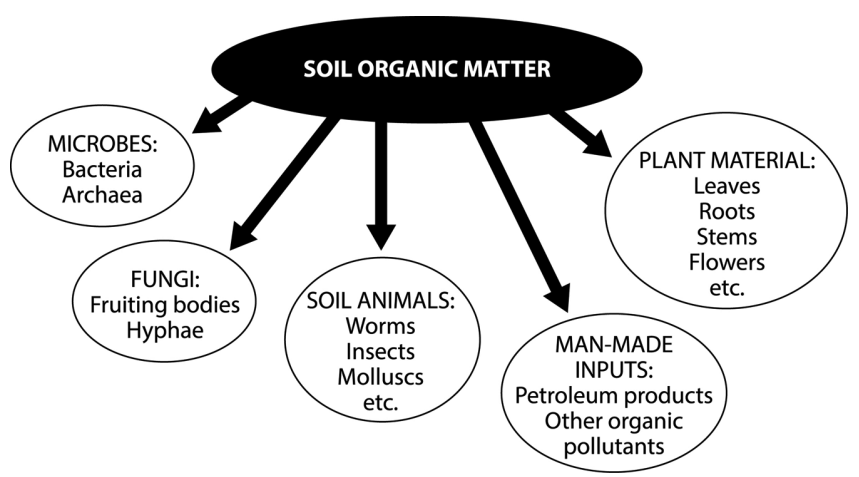

Figure 1. The many contributions to soil organic matter. 


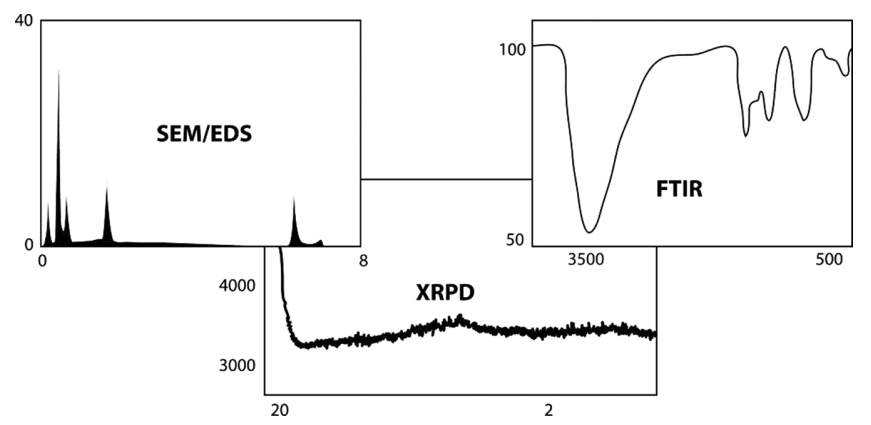

Figure 2. Example of the combined use of SEM/EDS, XRD, and FTIR to identify a sample of unknown origin. This confirms the identification of amorphous iron silicate.

analytes of interest, in particular as a first line methodology (Fig. 2). This is especially the case when FTIR is combined with other analytical procedures: DRIFT is combined with mid-infrared partial leastsquares (MIR-PLS) modelling or other chemometric techniques such as principal components analysis (PCA). MIR-PLS modelling has been developed and applied to soils to predict soil physicochemical properties (e.g., Nguyen et al., 1991) and has been applied to rapidly screen and compare crime scene samples. PCA, a statistical tool which models the spectral signatures from the various components in a sample, is a powerful discriminatory tool, providing an objective method of comparing the mid-infrared spectra of the soil samples being examined. However, presently such approaches still require much expert interpretation and depend on the existence of appropriate relevant related databases. FourierTransform infrared (FTIR) spectroscopy can also be used to qualitatively characterise the general soil organic constituents (such as fats, waxes, proteins, cellulose, hemicellulose and lignin) in soils.

\section{Spores}

Fossil pollen grains and grass spores are preserved in many soils, in particular those that are not strongly acidic. These reproductive particles are produced in large amounts by trees, shrubs and grasses and can readily be used for soil comparisons (e.g., Mildenhall et al., 2006; Pye, 2007; Murray, 2011; Wiltshire, 2015). Palynology (spore/pollen analysis) is a sub-discipline of botanical ecology and it has been shown to be of considerable use to the criminal investigator (Wiltshire, 2015; Adams-Groom, 2012). Pollen grains are produced in the anthers of flowers and can be characterised using a microscope (Fig. 3 shows the use of SEM in pollen grain identification). Pollen and spores (plant and fungal) provide clues as to the source of items and the characteristics of the environments from which the material has originated. They are generally abundant, resistance to mechanical and chemical destruction, small in size, and often have a distinct morphology, making them very useful. Their identification to an individual parent plant taxon can be related to a specific ecological habitat. Due to their microscopic size they can easily be picked up and transported away from scenes of interest without providing any visual clue to a suspect as to what has occurred (Mildenhall et al., 2006). As in all forensic analyses, and in particular where trace evidence is unseen with the naked eye, the importance of minimising risks of laboratory and cross-sample contamination during sub-sampling and preparation is recognised. Palynomorphs
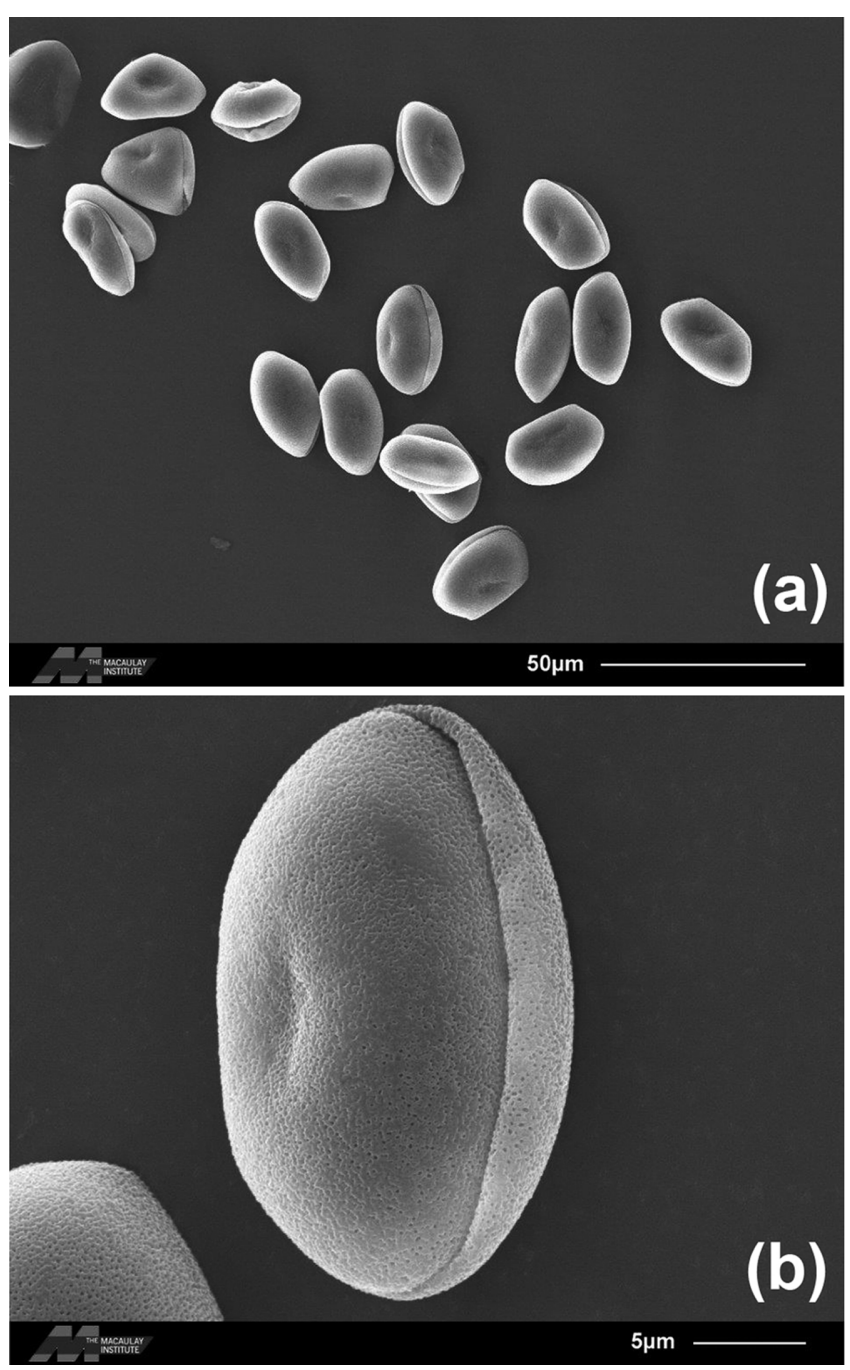

Figure 3. SEM images of snowdrop pollen spores (Source: Evelyne Delbos, James Hutton Institute).

can provide good trace evidence, fulfilling the requirements relating to the transfer, persistence, and detection of such evidence (Morgan et al., 2010a). In most countries, it is extremely under-utilized probably because it is labour intensive, needs considerable expertise and experience, can be difficult to quantify and quality control, and requires appropriate controlled and timely sample collection (Walsh and Horrocks, 2008).

It has been show that localised areas of similar vegetation type, even within the same geographic region, can have significantly different plant assemblages which can be used to improve discrimination (Horrocks et al., 1999). Nevertheless, some plant families such as the Poaceae and the Rosaceae are difficult to differentiate using palynology. A study by Riding et al. (2007) showed that when mixing occurs from wearing footwear at different sites, the pollen/spore content of the footwear predominantly reflects that of the last site visited. Occasionally, fungal spores, which can grow on materials such as stone, brick, tiles, paving stones, wooden objects, and leather have also been used as trace evidence in case work (Hawksworth and Wiltshire, 2011). Significant assemblages of palynomorphs are picked up from bare soil, mud, leaf litter organic debris and vegetation. However, even if discrete soil patches can be identified on soles, it is rare for perfectly 
uncontaminated samples to be obtained and as a consequence the palynological profile will mainly contain a mixed assemblage.

Opal phytoliths (silica-rich) and calcium phytoliths are mineral deposits that form in and between plant cells. Marumo and Yanai (1986) used opal phytoliths to differentiate soils with similar mineralogy.

\section{Organic Marker Analysis}

Other emerging soil forensic methods for soil comparison is the use of plant organic marker analysis (summarised in Dawson et al., 2008; Dawson and Hiller, 2010; Dawson and Mayes, 2015). Soil organic matter consists of the dead and decomposing plant, animal and microbial remains and the living microbiota and plant roots (Fig. 1). In general the largest component of soil organic matter is humus, which is a relatively stable material originating from highly decomposed biological material. The humic fraction comprises a variety of organic materials (complex polysaccharides, lipid and wax compounds, humic acids, suberin, cutin, etc.). In most soils the organic matter is derived primarily from litter from local vegetation, although managed soils (agricultural, municipal, or residential) may also receive organic inputs arising from the application of a range of manures, slurry, composts or mulches. This provides potentially unusual resultant organic profiles, of considerable use in forensic comparison.

The compounds found in the humic soil fraction are considered relatively resistant to decomposition and can persist for thousands of years. Organic compounds with high turnover rates, such as most carbohydrates, proteins and nucleic acids, are mainly of less use for forensic comparison than compounds with slower turnover rates, which are likely to provide a more robust profile over time and allow comparisons to be made between samples taken at different times, such as the period that may result between the sampling of crime scene samples and the recovery of samples from questioned items. However, while the complex nature of polymeric materials such as humic acids, lignin, suberin, cutin and tannins in soil may describe the soil organic matter, they are difficult to characterise, separate and analyse quantitatively.

The relative abundances of individual organic compounds can vary considerably between soil samples. Long-lived compounds can be quantitatively analysed as discrete compounds, and be very useful markers in soils for forensic investigations (Mayes et al., 2009; Dawson and Mayes, 2015). These organic compounds originate from plant, animal, fungal and microbial biomass within the soil, and also from faecal material and man induced additions to the soil, including composts and manures. Particularly in the topsoil, the most common and most studied long-lived lipid compounds are those originating from the surface wax of plants, which enter the soil as leaves and other plant litter. Plant wax compounds are useful as organic markers in soil forensic science because the patterns of these compounds in soil reflect the patterns of the same compounds in the plants associated with that soil (van Bergen et al., 1998). Their longevity in soil and ease of analysis are also advantageous for such an application. They are regularly used in court in the UK as evidence and as intelligence to ascertain likely source habitat of an unknown sample.

Plant wax compounds are complex mixtures of lipids consisting mainly of aliphatic compounds with relatively long carbon chains. The most common are hydrocarbons, aldehydes, and free and esteri-

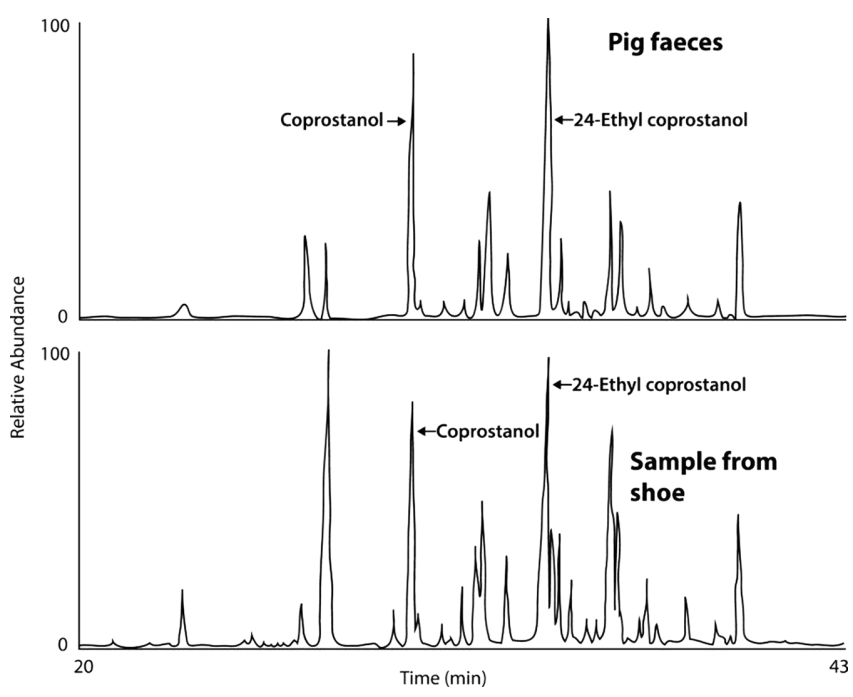

Figure 4. GCMS chromatograms of derivatized alcohol/sterol extracts from a soil sample collected from a suspect's shoe and a sample of pig faeces collected from a crime scene showing faecal stanols used as part of the evidential case comparison.

fied long-chain fatty alcohols and fatty acids. Whilst the highest order plants contain these compounds, the relative proportions of individual compounds can differ greatly between plant species, and in some instances, between different parts of the same plant (Dawson et al., 2000; Smith et al., 2001). Patterns of organic compounds in soil, originating from plant waxes ( $n$-alkanes and long-chain fatty alcohols), are the same as the patterns found in the associated vegetation (Dawson et al., 2004). The lipid profile of a soil represents the product of the synthesis and decomposing processes on the vegetation, all of which are determined by the soil environment. The soil $n$-alkane profile pattern reflects that of the contributing mixture of vegetation and can persist in soil for centuries (Dawson et al., 2004). The wax from certain plant groups may also contain, in high concentrations, individual secondary alcohols (e.g., 10-nonacosanol in conifer species) and long-chain ketones (e.g., 15-nonacosanone in Brassica spp.) which are also useful organic markers in soils.

Wax marker analysis involves the separation into different compound classes by liquid (solid phase extraction) chromatography and analysis of individual compounds by gas chromatography (GC) or gas chromatography-mass spectrometry (GCMS). Other lipid compounds present in the sample with similar properties, will also appear in the associated GC or GCMS chromatograms (e.g., Fig. 4). The identification and quantification of these additional compounds can also be useful as organic lipid markers in forensic studies. Many of these compounds, such as plant sterols and triterpenoids, may originate from vegetation and are reflective of the individual plant types associated with the soil (Dawson and Mayes, 2015).

\section{Plant Fragments}

Forensic soil samples can contain plant fragments, which until recently have received little attention. They potentially can, in addition to the soil or geological material, adhere to footwear, clothing, tools or be transferred to areas of contact (e.g., Fig. 5). A large varia- 

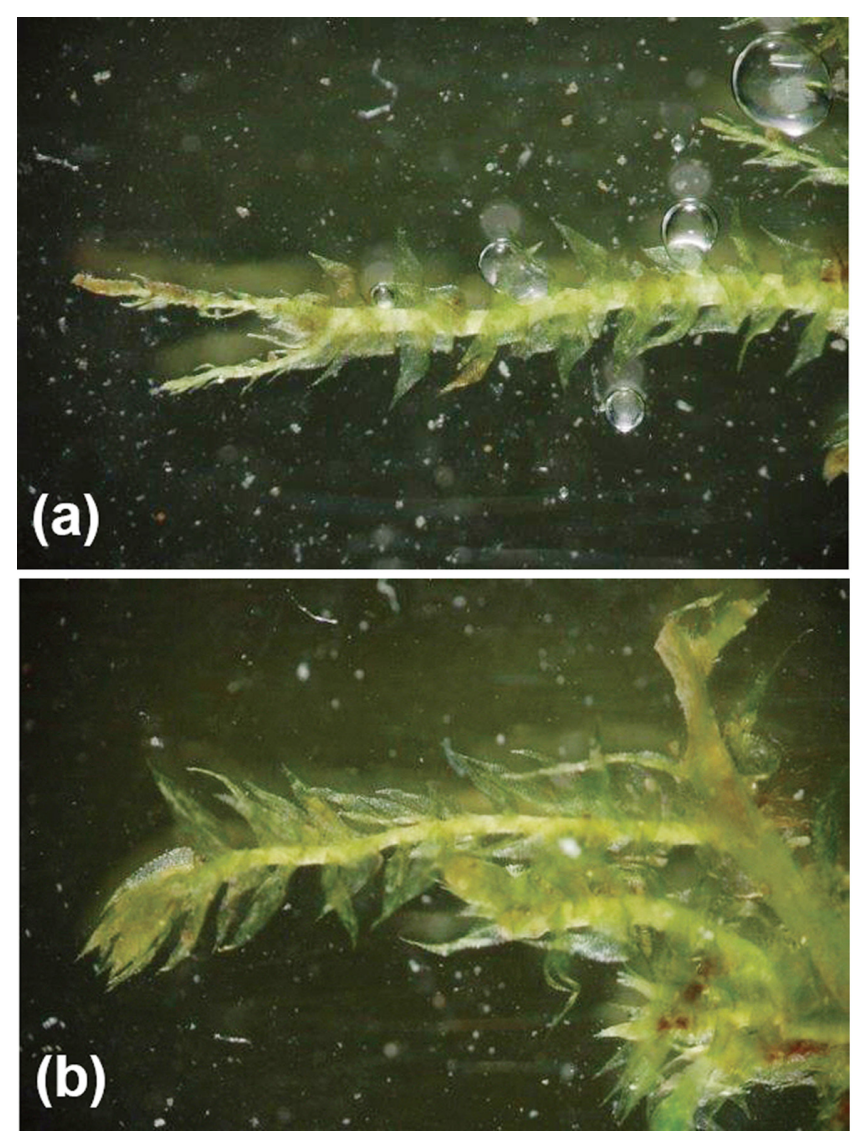

Figure 5. Trace plant fragments can be identified using microscopy from questioned items and compared with what is observed to be at the crime scene. A fragment of a moss Kindbergia praelonga (Common Feather-moss), was found in the sample from the base of the grave of a victim (a) and the same moss species Kindbergia praelonga (Common Feather-moss) was found on the blade of the questioned spade (b). White bar represents $2 \mathrm{~mm}$.

tion in plant species exists making botanical evidence potentially important. Species can be identified using a traditional microscope by morphology or plant fragments can be characterised using a molecular approach (Linacre et al., 2005; Ferri et al., 2009). Bryophytes can be useful to provide botanical evidence for forensic investigations (Virtanen et al., 2007). Plant Fragment DNA Analysis can potentially be carried out if DNA can be extracted (Dawson et al., 2008).

\section{Microbial Biomarkers}

There is also potentially a great diversity of living organisms in the soil with features which can be analysed and compared. The species and relative abundances of organisms living in soil, and associated with soil, are very much influenced by soil chemistry (e.g., $\mathrm{pH}$ and elemental composition), physical structure (e.g., particle size) and the environmental conditions (e.g., temperature and precipitation). The decomposing introduced inputs, in addition to the natural inputs, provide a vast diversity of biochemical signatures, in addition to observed physical remains of specific organisms.

Diatom remains provide a good record of past and present habitats as a result of their siliceous skeletons which can persist for a long time unseen on objects. They have been used to compare samples that had been in contact with water for the investigation of time of death as a result of drowning (Cameron, 2004). Phytoliths, the plant opal silica structure that accumulates in some plants, has been used to differentiate soils with otherwise similar mineralogy (Marumo and Yanai, 1986). Testate amoebae also have potential for use for site discrimination. Amoebae could be recovered from dried sediment residue on clothing after ten years and despite concentrations being low, when combined with XRPD mineralogical data, the outcome was successful (Swindles and Ruffell, 2009).

Microbial community characterization using a variety of molecular biological techniques has the potential to be used more widely than it currently is. The soil microbial community has been shown to be affected by soil type, land management and their environment (Singh et al., 2009). However, the development of molecular methods has overcome the problems associated with methods which rely on microbial culturing. Nucleic acid techniques are those that target analysis of the genetic information of organisms encoded in their DNA and RNA. The highest precision of these techniques is the complete analysis of DNA sequences. General procedures for investigating microbial communities involve the extraction and purification of the DNA from the sample and then amplification using the PCR followed by analysis of the nucleotide sequence.

The specificity of all techniques used to characterise the microbial community depends, however, on the conditions and primers used, and in many cases may detect only the dominant members of the microbial community. There is still a significant amount of work to be done to ensure the resolution and sensitivity is appropriate and that the community has not altered as a result of changes in moisture or temperature as a result of time differences between time of control sample collection and time of recovery of questioned items. Compared to human DNA as evidence, where the human target is a discrete entity with a unique DNA profile which is fixed at conception, the soil target is not so clearly defined.

A consideration with adoption of the method is the minimum amount of soil that can be used to obtain sufficient DNA for extraction and that it also represents a true reflection of the entire community as the amount of soil obtained from an exhibit such as a shoe or clothing item may often be small. Furthermore, standardised extraction methods suitable for a range of soil types need to be instituted which are the least affected by inhibitory substances. Challenges still require to be resolved in this area (Sensabaugh, 2009) before being robust enough to be adopted in case work. Bacterial profiling methods have been used to predict a possible common source of soil samples from the same soil type (Quaak et al., 2012). Several soil forensic studies have been reported in Petrisor et al. (2006) to show that a soil bacterial community DNA profile can be obtained from small samples of soil recovered from potential crime scenes (e.g., shoes or clothing) with the profiles being representative of the site of collection (e.g., See the MiSAFE project concept of the use of soil DNA, Fig. 6). However, as such living aspects of soil can be influenced by environmental conditions such as wetting and drying, which can change between sampling times between questioned and control samples, care has to be taken in obtaining robust profiles for forensic comparison (Macdonald et al., 2008; Habtom et al., 2016). While there is potential for the forensic use of soil microbial bacterial communities (Demaneche, 2017), it is currently only 


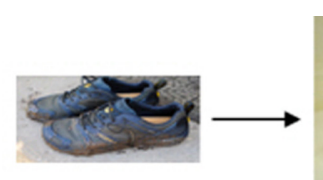

Soil $(0.25 \mathrm{~g})$

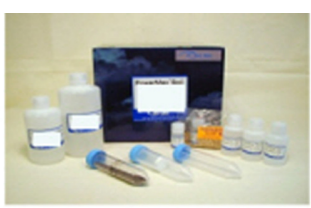

DNA extraction

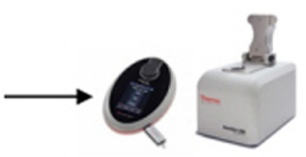

DNA quantification, purity

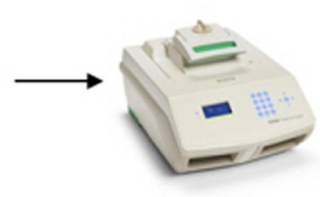

Marker gene amplification

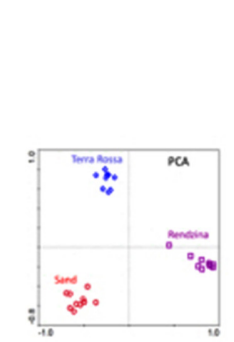

Data analysis and statistical analysis

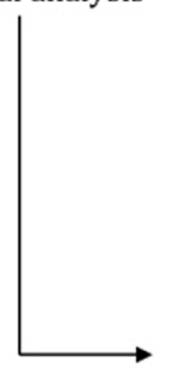

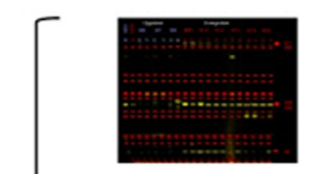

DNA fingerprinting

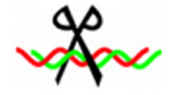

Amplification product processing and purification
A

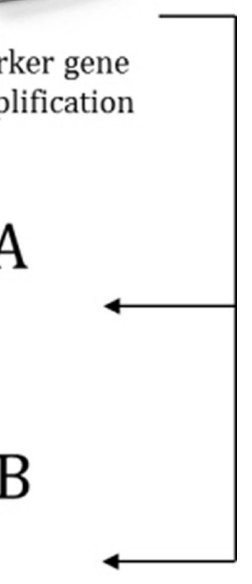

Soil forensics use in courts of Law

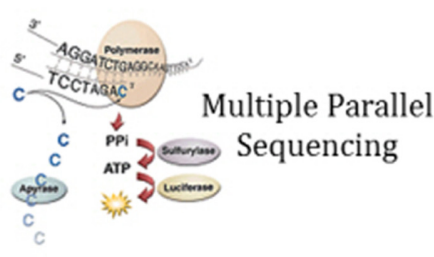

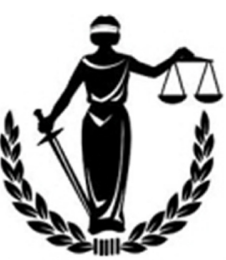

Figure 6. Proposed approach to using soil DNA characterisato
Edouard Jurkevitch, The Hebrew University of Jerusalem).

used in case work of a few countries, such as Spain, Italy and The Netherlands.

\section{Markers of Mammalian Decomposition}

Cholesterol, the major sterol from animals, can be found in soils. Whilst its presence could be due to soil fauna (living or dead), high levels of cholesterol have been found in soils which have been in contact with, or close to decomposing bodies, both recent and ancient. Soil cholesterol has also been associated with the presence of faecal material and derived products, such as animal manure and sewage sludge in ancient graves (Davies and Pollard, 1987).

In a study with pigs as human analogues it was shown that soil which had been in contact with decomposing pig cadavers had raised levels of cholesterol, coprostanol and epicoprostanol (von der Lühe et al., 2013) (Fig. 7). Epicoprostanol was also detected in adipocere collected from human bodies which had been immersed in seawater for up to four years (Adachi et al., 1997).

Other chemical compounds such as putrescence and cadaverine, which are produced by the breakdown of amino acids in living and dead organisms have been shown experimentally to indicate in soil water samples the close presence of a porcine cadaver (personal com- munications, Pringle, university of Keele; Donnelly et al., 2016).

Although the coprostanol:24-ethylcoprostanol ratio discriminates between herbivores and omnivores, other faecal markers are needed to further identify the animal source. The faeces from pigs and humans have similar coprostanol:24-ethylcoprostanol ratios but can be discriminated using their patterns of bile acids (Bull et al., 2002). Faeces from ruminants (e.g., cattle, sheep and goats) can be discriminated from non-ruminant herbivores (e.g., horses and rabbits) using archaeol as a marker (Gill et al., 2010). This compound has also been found in some sewage sludges, likely due to anaerobic digestion processes occurring at sewage treatment plants.

$n$-alkanes and fatty alcohols and other organic compounds of biological origin, are found in the organic matter of most soils. The discriminating power of these compounds for the comparison of soil samples is based on the findings that the concentrations and patterns of these compounds can differ greatly between different soil samples, due largely to differences in the species composition of the vegetation which was the original source of the compounds.

The soil vapour phase has been considered to be used in association with the use of cadaver dogs to search for bodies. Although studies have generally featured a relatively small number of odiferous volatile organic compounds (or termed VOCs) likely to be produced in large quantities, including volatile short-chain fatty acids (mainly 


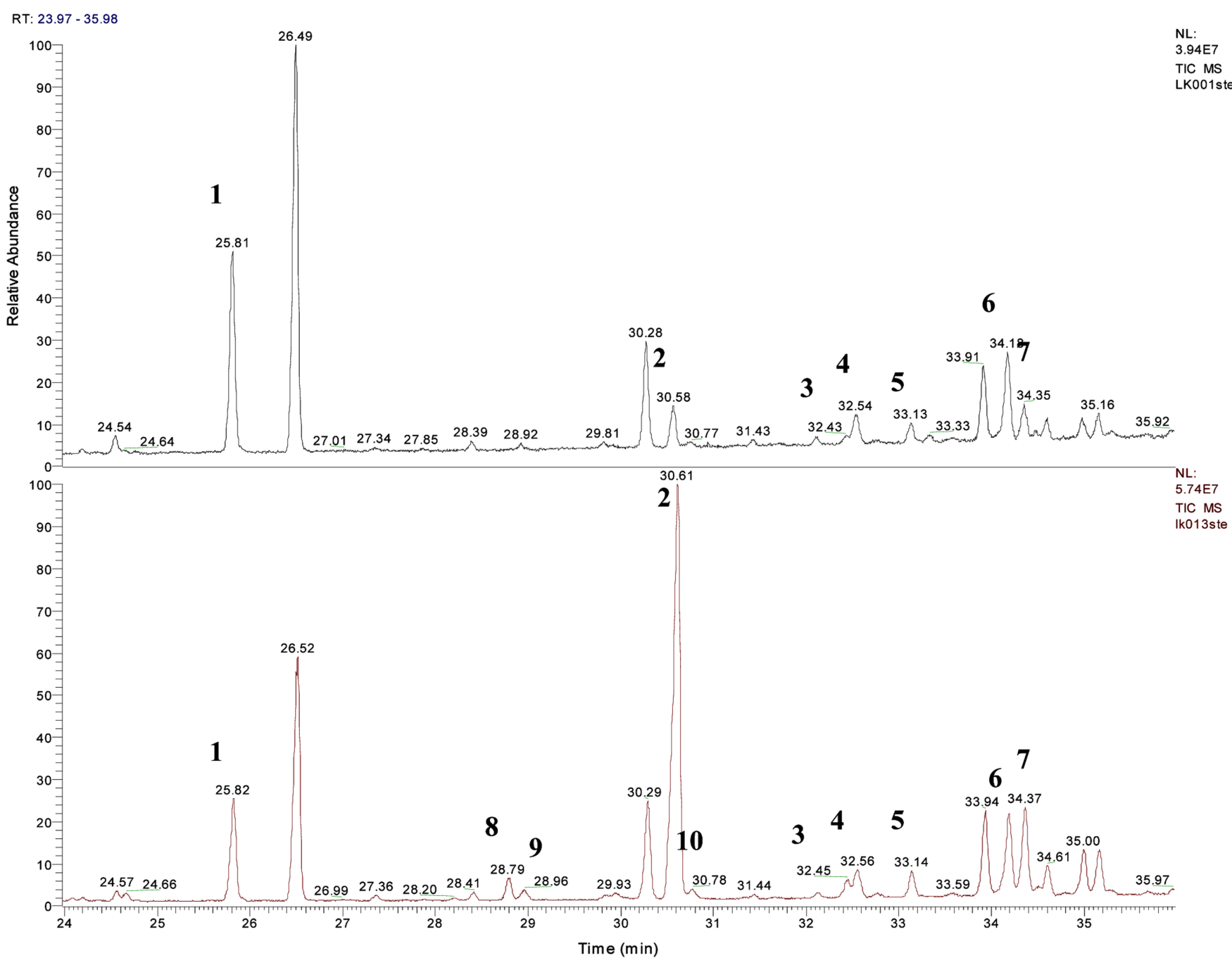

Figure 7. Cholesterol and coprostanol compounds, indicative of human decomposition products in a study involving pig surrogates. Top chromatogram sample of a pig at $20 \mathrm{~cm}$ depth, day 0; lower chromatogram of the same pig, $20 \mathrm{~cm}$ depth, day 17; quantified compounds. Sterol Internal Standard (1), cholesterol (2), 24-ethylcoprostanol (3), 24-ethylepicoprostanol (4), stigmasterol (5), $\beta$-sitosterol (6), stigmastanol (7), coprostanol (8), epicoprostanol (9), and cholestanol (10).

acetate and butyrate) and amines, such as putrescene and cadaverine, more sophisticated analytical methodologies have shown that a very large number of volatile decomposition products can be detected in the soil vapour phase (e.g., Vass et al., 2008). It has been demonstrated that some of these compounds can remain in the soil many years after deposition of a body (Vass, 2012).

As more research is carried out on indicator compounds, there will ensue a greater predictive power also for estimations of time after death. Currently a method based on the process of soft tissue decomposition, with analysis of the chemicals called volatile fatty acids being produced predicting time after death by accumulated degree days (ADDs, Fig. 8). The production and disappearance of these five acids are time dependent and from this an approximation of TAD can be produced (Vass, 2011).

Water-soluble components of body decomposition would be expected to enter the soil water phase with the potential to move with any flow of soil water; the degree of movement would not only depend on water flow, but the relative affinities of the decomposition product for different solid components of the soil. Although most water-soluble

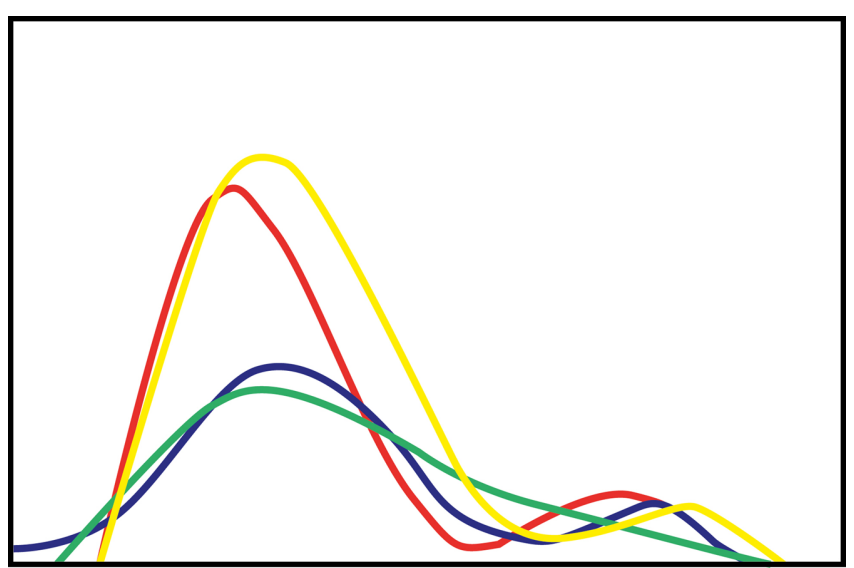

ADD - Accumulated Degree Days (C)

* 1285 ADD

Figure 8. Amount of volatile fatty acids (y axis) help indicate the time after death (ADDs, $x$ axis) (Vass, 2011).

decomposition products consist mostly of inorganic ions, including ammonium, nitrate and phosphate, soluble products of protein decomposi- 


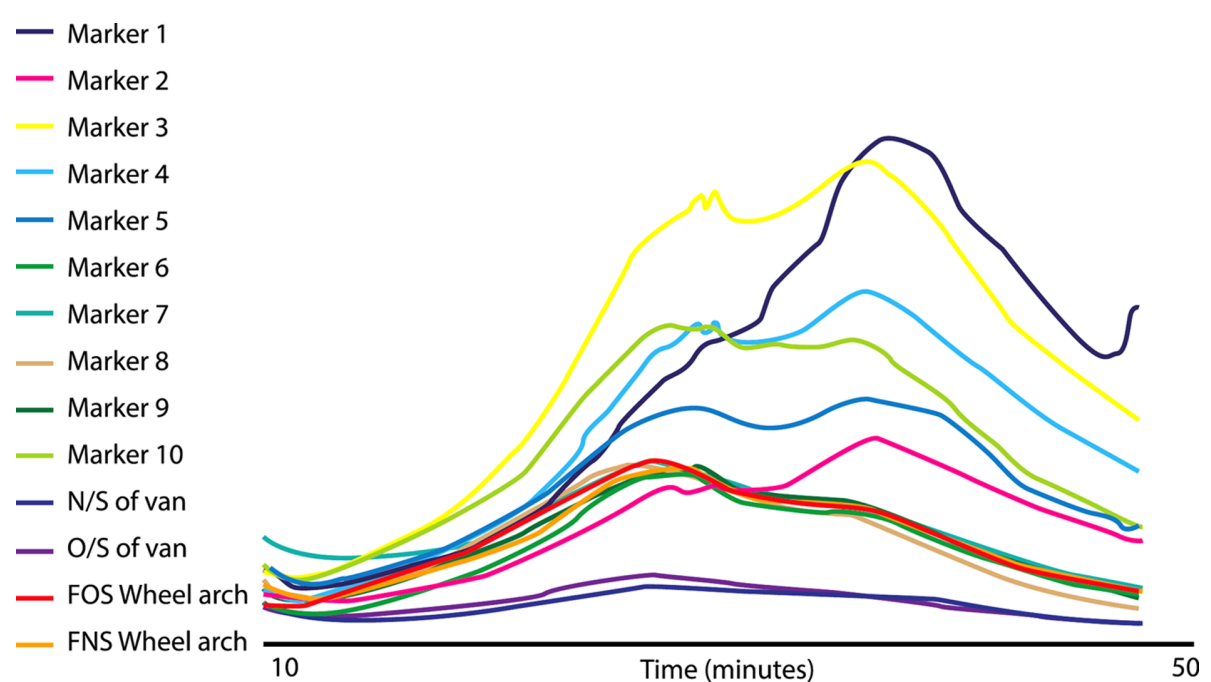

Figure 9. Long lived organic pollutants associated with roads and motor vehicles can be measured in evidential questioned soil samples (FOS Wheel arch and FNS Wheel arch) and compared with crime scene samples (Markers 6, 7, and 8). Other profiles reflect the alibi and other tracks in the neighbourhood.

tion (amino acids and amino acid breakdown products) have been considered as grave soil markers, being detectable using ninhydrin reagent (e.g., Carter et al., 2008).

Organic decomposition products which are insoluble in water are likely to be relatively immobile in the soil and remain close to the location of the body. Such compounds originate primarily from body lipids, such as adipose tissue. During the formation of adipocere, body fats are hydrolysed to free fatty acids. Adipocere has a characteristic fatty acid composition. In general, long chain fatty acids are less persistent in soils than long chain $n$-alkanes, fatty alcohols, and steroids (sterols and stanols).

Long-lived organic compounds associated with human activity, such as organic pollutants associated with roads and motor vehicles, from industrial activities and urban areas can be found in soils near roads and cities, e.g., petroleum hydrocarbons (Jardé et al., 2005; Mayes et al., 2012; West et al., 2013) as well as polycylic aromatic hydrocarbons (PAHs). If contact is made with this surface soil, the anthropogenic organic profiles are transferred to the contact surface (i.e., footwear, vehicles, etc.). The profiles found in the questioned soil can then be compared with the soil profiles at the crime scene (Fig. 9) and were seen to be indistinguishable from the profile at that location. Comparison of Unresolved Complex Mixture (UCM) humps in track soils, soils from near a burnt out van and from Suspect Car's wheel arches can be made. The low volatility petroleum hydrocarbons (e.g., oil and tar) are often characterised by a 'hump', which is a complex mixture of poorly separated compounds (Fig. 9) and can be distinctive to patches of track or road to within a few $\mathrm{cm}$ distance.

\section{Evaluation of Soil Organic Profile Characteristics}

The spatial variability in soil mineralogy is largely due to spatial distribution reflecting differing geology. The variability in organic characteristics is largely due to the varied surface spatial distribution and contribution of the organic material over time, of decomposing plant species and other organisms. Organic characteristics generally vary at a smaller spatial scale of resolution than inorganic (e.g., that of a foot step, or a car tyre contact point). Such input characteristics also vary with depth, which can be useful in ascertaining depth of contact trace material case context; depth of sampling is vitally important when comparing soil from a specific locus with soil on the questioned item.

Since soils are continuous and varying in both a horizontal and a vertical dimension, no two soil samples can be absolutely identical, but the complexity of soil characteristics can provide powerful analytical profiles for comparative purposes. Furthermore, the fact that different soil component compositions (e.g., mineral and organic fractions) can be largely independent of each other and together can enhance the evidential value of such soil comparisons.

Soils have varying proportions of inorganic and organic constituents and due to the complex nature of soil, analysis of the different components can provide complementary and independent types of information. The presence of rare compounds can be particularly useful, especially where there is a mixed sample, as can be experienced in case work. It is often the presence of unusual minerals or unusual organic compounds that make a strong association/link between an object or person and a place.

There is still so much information in soils to further unlock, in particular from the organic component which holds so much information about the specific environment from which it came, whether that is for search, intelligence, crime reconstruction or for evaluative evidential purposes. These organic compounds also can help indicate where a body is buried or has been located in the past. These are exciting times for geologists, soil scientists, organic chemists, biologists, microbiologists and DNA experts to join together with practitioners to develop even better, more accurate, faster and complementary tools for use at the crime scene through to communication of expert evidence in court.

\section{References}

Adachi, J., Ueno, Y., Miwa, A., Asano, M., Nishimura, A., and Tatsuno, Y., 1997, Epicoprostanol found in adipocere from five human autopsies: Lipids, v. 32, no. 11, pp. 1155-1160.

Adams-Groom, B., 2012, Forensic Palynology. in Marquez-Grant, N., and Roberts, J. (eds.), Forensic ecology handbook: from crime scene to court: Wiley, Chichester, pp. 153-167.

Bruce, R.G., and Dettmann, M.E., 1996, Palynological analysis of Australian surface soils and their potential in forensic science: Forensic Science International, v. 81, pp. 77-94.

Bull, I.D., Lockheart, M.J., Elhmmali, M.M., Roberts, D.J., and Evershed, R.P., 2002, The origin of faeces by means of biomarker detection: Environment International, v. 27, pp. 647-654.

Bull, P.A., and Morgan, R.M., 2007, Sediment fingerprints: a forensic technique using quartz sand grains - a response: Science and Justice, v. 47, no. 3, pp. 141-144. 
Cameron, N.G., 2004, The use of diatom analysis in forensic geoscience. in Pye, K., and Croft, D.J. (eds.), Forensic geoscience: principles, techniques and applications: Geological Society London, Special Publication, pp. 277-280.

Carter, D.O., Yellowlees, D., and Tibbett, M., 2008, Using ninhydrin to detect gravesoil: Journal of Forensic Science, v. 53, pp. 397-400.

Davies, G.R., and Pollard, A.M., 1987, Organic residues in an Anglo-Saxon grave: Science and archaeology, Glasgow 1987: Proceedings of a Conference on the Application of Scientific Techniques to Archaeology, Glasgow, September, pp. 391-402.

Dawson, L.A., Mayes, R.W., Elston, D.A., and Smart, T.S., 2000, Root hydrocarbons as potential markers for determining species composition: Plant, Cell and Environment, v. 23, pp. 743-750.

Dawson, L.A., and Hillier, S., 2010, Measurement of soil characteristics for forensic applications: Surface and Interface Analysis, v. 42, pp. 363377 .

Dawson, L.A., and Mayes, R.W., 2014, Criminal and environmental soil forensics: soil as physical evidence in forensic investigations. in Murphy, B.L., and Morrison, R.D. (eds.), Introduction to environmental forensics ( $3^{\text {rd }}$ edition): Academic Press, Oxford, pp. 457-486.

Dawson, L.A., Towers, W., Mayes, R.W., Craig, J., Vaisanen, R.K., and Waterhouse, E.C., 2004, The use of plant hydrocarbon signatures in characterizing soil organic matter. in Pye, K., and Croft, D.J. (eds.), Forensic geoscience: principles, techniques and applications: Geological Society London, Special Publication, v. 232, pp. 269-276.

Dawson, D.A., Campbell, C.D., Hillier, S., and Brewer, M.J., 2008, Methods of characterising and fingerprinting soils for forensic application. in Tibbett, M., and Carter, D.O. (eds.), Soil analysis in forensic taphonomy: chemical and biological effects of buried human remains: CRC Press, London.

Donnelly, L.J., Cassella, J., Pirrie, D., Dawson, L., Harrault, L., Blom, G., Davidson, A., Arnold, P., Harrison, M., and Ruffell, A., 2016, Analysis of leachate, VOCs, fatty acids and mineralogy following the discovery of a homicide grave: Potential implications for police led open area ground searches for burials: $35^{\text {th }}$ International Geological Congress, Cape Town, August 29, T6.1 - Forensic Soil Science and Geology.

Demaneche, S., Schauser L., Dawson L.A., Franqueville L., and Simonet, P., 2017, Microbial soil community analyses for forensic science: Application to a blind test: Forensic Science International, v. 270, pp. 153-158.

Ferri, G., Alu, M., Corradini, B., Radheshi, E., and Beduschi, G., 2009, Slow and fast evolving markers typing in Modena males (North Italy): Forensic Science International, v. 3, no. 2, pp. 31-33.

Gill, F.L., Dewhurst, R.J., Dungait, J.A.J., Evershed, R.P., Ives, L., Li, C.S., Pancost, R.D., Sullivan, M., Bera, S., and Bull, I.D., 2010, Archaeolda biomarker for foregut fermentation in modern and ancient herbivorous mammals?: Organic Geochemistry, v. 41, pp. 467-472.

Habtom, H., Demaneche, S., Dawson, L.A., Azulay, C., Matan, O., Robe, P., Gafny, R., Simonet, P., Jurkevitch, E., and Pasternak, Z., 2016, Soil characterisation by bacterial community analysis for forensic applications: a quantitative comparison of environmental technologies: Forensic Science International, v. 26, pp. 21-29.

Hawksworth, D.L., and Wiltshire, P.E.J., 2011, Forensic mycology: The use of fungi in criminal investigations: Forensic Science International, v. 206, pp. 1-11.

Horrocks, M., Coulson, S.A., and Walsh, K.A.J., 1999, Forensic palynology variation in the pollen content of soil on shoes and in shoeprints in soil: Journal of Forensic Science, v. 44, pp. 119-122.

Jardé, E., Mansuy, L., and Faure, P., 2005, Organic markers in the lipidic fraction of sewage sludges: Water Research, v. 39, pp. 1215-1232.

Linacre, A., Hsieh, H., and Lee, J.C., 2005, Case study: DNA profiling to link drug seizures in the United Kingdom. in Coyle, H.M. (ed.), Forensic botany: principles and applications to criminal casework: CRC Press, Boca Raton, pp. 163-166.

Macdonald, L., Singh, B., Thomas, N, Brewer, M.J., Campbell, C.D., and Dawson, L.A., 2008, Microbial DNA profiling by multiplex terminal restriction fragment length polymorphism for forensic comparison of soil and the influence of sample condition: Journal of Applied Microbiology, v. 105, no. 3, pp. 813-821.

Marumo, Y., and Yanai, H.J., 1986, Morphological analysis of opal phytoliths for soil discrimination in forensic science investigation: Journal of Forensic Sciences, v. 31, pp. 1039-1049.

Mayes, R.W., Macdonald, L.M., Ross, J.M., and Dawson, L.A., 2009, Discrimination of domestic garden soils using plant wax compounds as markers. in Ritz, K., Dawson, L.A., and Miller, D. (eds.), Criminal and environmental soil forensics: Springer, London, pp. 463-476.

Mildenhall, D.C., Wiltshire, P.E.J., and Bryant, V.M., 2006, Forensic palynology: why do it and how it works: Forensic Science International, v. 163, pp. 163-172.

Morgan, R.M., French, J., O’Donnell, L., and Bull, P.A., 2010a, The reincorporation and redistribution of trace geoforensic particulates on clothing: Science and Justice, v. 50, pp. 195-199.

Morgan, R.M., Robertson, J., Lennard, C., Hubbard, K., and Bull, P., 2010b, Quartz grain surface textures of soils and sediments from Canberra, Australia: A forensic reconstruction tool: Australian Journal of Forensic Sciences, v. 42, pp. 169-179.

Murray, R.C., 2011, Evidence from the Earth: Forensic geology and criminal investigation ( $2^{\text {nd }}$ edition). Mountain Press, Missoula, 200 p.

Nguyen, T.T., Janik, L.J., and Raupach, M., 1991, Diffuse reflectance infrared Fourier transform (DRIFT) spectroscopy in soil studies: Australian Journal of Soil Research, v. 29, pp. 49-67.

Petrisor, I.G., Parkinson, R.A., Horswell, J., Waters, J.M., Burgoyne, L.A., Catchside, D.E.A., Dejonghe, W., Leys, N., Vanbroekhoven, K., Dattnaik, P., and Graves, D., 2006, Microbial forensics. in Morrison, D., and Murphey, B.L. (eds.), Environmental forensics: contaminant specific guide: Academic Press, San Diego.

Pye, K., 2007, Geological and soil evidence: forensic applications: CRC Press, Boca Raton, $335 \mathrm{p}$.

Quaak, F.C.A., and Kuiper, I., 2011, Statistical data analysis of bacterial t-RFLP profiles in forensic soil comparisons: Forensic Science International, v. 210, pp. 96-101.

Riding, J.B., Rawlins, B.G., and Coley, K.H., 2007, Changes in soil pollen assemblages on footwear worn at different sites: Palynology, v. 31, pp. 135-151.

Robertson, A.J, Main, A.M, Robinson, L.J., and Dawson L.A., 2015, In situ FTIR analysis of soils for forensic applications: Spectroscopy, v. 30, no. 8, pp. 22-30.

Ruffell, A., Pirrie, D., and Power, M.R., 2013, Issues and opportunities in urban forensic geology. in Pirrie, D., Ruffell, A., and Dawson, L.A. (eds.), Environmental and criminal geoforensics: Geological Society of London, Special Publications, v. 384, pp. 147-161.

Sensabaugh, G., 2009, Microbial community profiling for the characterisation of soil evidence: forensic considerations. in: Ritz, K., Dawson, L.A., and Miller, D. (eds.), Criminal and environmental soil forensics: Springer, London, pp. 49-60.

Singh, B., Dawson, L., and Macdonald, L., 2009, Impact of biotic and abiotic interaction on soil microbial communities and functions: a field study: Applied Ecology, v. 41, pp. 239-248.

Smith, D.G., Mayes, R.W., and Raats, J.G., 2001, Effect of species, plant part, and season of harvest on $n$-alkane concentrations in the cuticular wax of common rangeland grasses from southern Africa: Australian Journal of Agricultural Research, v. 52, pp. 875-882.

Swindles, G., and Ruffell, A., 2009, A preliminary investigation into the use of testate amoebae for the discrimination of soil samples: Science and Justice, v. 49, pp. 182-190.

van Bergen, P.F., Nott, C.J., Bull, I.D., Poulton, P.R., and Evershed, R.P., 1998, Organic geochemical studies of soils from the Rothamsted Classical Experiments - IV. Preliminary results from a study of the effect of soil pH on organic matter decay: Organic Geochemistry, v. 29, no. 5, pp. 1779-1795.

Vass, A.A. 2011, The Elusive universal post-mortem interval formula: 
Forensic Science International, v. 204, pp. 34-40.

Vass, A.A., 2012, Odor mortis: Forensic Science International, v. 222, pp. 234-241.

Vass, A.A., Smith, R.R., Thompson, C.V., Burnett, M.N., Dulgerian, N., and Eckenrode, B.A., 2008, Odor analysis of decomposing buried human remains: Journal of Forensic Sciences, v. 53, no. 2, pp. 384-392.

von der Lühe, B., Dawson, L.A., Mayes, R.W., Forbes, S., and Fiedler, S., 2013, Investigation of sterols as potential biomarkers for the detection of pig (S. s. domesticus) fluid in soils: Forensic Science International, v. 230, pp. 68-73.

Virtanen, V., Korpelainen, H., and Kostamo, K., 2007, Forensic botany: usability of bryophyte material in forensic studies: Forensic Science
International, v. 172, pp. 161-163.

Walsh, K.W., and Horrocks, M., 2008, Palynology: its position in the field of forensic science: Forensic Science, v. 53, pp. 1053-1060.

West, C.E., Scarlett, A.G., Pureveen, J., Tegelaar, E., and Rowland, S.J., 2013, Abundant naphthenic acids in oil sands process-affected water: Studies by synthesis, derivatisation and two-dimensional gas chromatography/high-resolution mass spectrometry: Rapid Communications in Mass Spectrometry, v. 27, pp. 357-365.

Wiltshire, P.E.J., 2010, Forensic ecology. in White, P.C. (ed.), Crime scene to court: The essentials of forensic science: RSC Publishing, Cambridge, pp. 54-85.

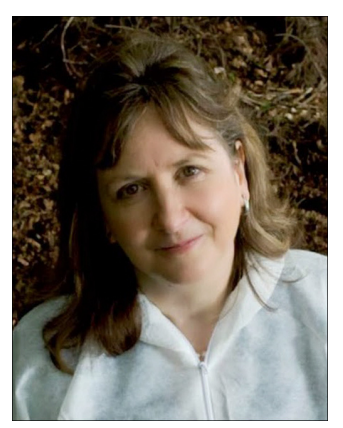

Lorna Dawson BSc (Hons), PhD, is Head of Forensic Soil Science at the James Hutton Institute, visiting Professor at Robert Gordon University, a Chartered Scientist a Fellow of the Institute of British Soil Scientists and a Fellow of the Royal Society of Arts. She has worked on over 100 cases with police forces and agencies across the UK and overseas, in soil trace evidence and search. She is a member of the National Crime Agency, holds diplomas in civil and criminal law $(2011,2012)$ and regularly attends court as an expert witness. She sits on the British Association of Science General Committee and holds a diploma in Science Communication (2010). 